\title{
LOS FRISOS DEL PARTENÓN EN CHILE
}

El día 14 de abril de 2009 se han inaugurado oficialmente en la Estación Grecia del Metro réplicas de parte del friso del Partenón. Se trata de una donación del Ministerio de Cultura de Grecia, originada en una iniciativa de la señora Sofía Prats, embajadora de Chile en ese país, e implementada con el apoyo entusiasta de la Embajadora de Grecia, señora Chryssoula Karykopoulou. Los quince paneles de un metro de alto por 1,2 de ancho que podemos ver en una magnífica ubicación y con perfecta iluminación, nos permiten imaginar lo que fue el friso original, de 260 metros de longitud, que representaba la procesión de las Panateneas.

Indudablemente aquel friso constituyó una obra única del arte mundial, y parte inseparable de un monumento también único, el Partenón. Creemos que la instalación de estas réplicas es un valiosísimo aporte a la cultura de nuestra ciudad y del país. Más allá de tantos «eventos» que pasan y nada dejan en el espíritu, desapareciendo tras el bullicio de la propaganda, este aporte permite que la Estación Grecia del Metro ofrezca duraderamente a todo ciudadano la oportunidad de contemplar cuantas veces desee una maravillosa obra de arte. Y al mirarla, no se puede menos que pensar qué terrible daño se hizo en 1801 al arrancar del Partenón paneles del friso para llevarlos a Inglaterra. En ese caso, no se trató de un trozo de mármol encontrado casualmente, desenterrado y comprado al dueño del terreno, sino del desmembramiento de una obra de arte que sin duda pertenece no sólo al pueblo griego sino a toda la humanidad.

Por eso, a 200 años de aquella acción, y siendo tanto Grecia como Gran Bretaña integrantes de la Unión Europea, es justo apoyar la petición helénica para que vuelvan a esas piezas al lugar sagrado para la cultura universal: la Acrópolis de Atenas. El Comité Chileno constituido para apoyar esa causa, que preside el ex senador y ex canciller señor Gabriel Valdés, seguramente podrá renovar ahora sus planteamientos 